\title{
EKSTRAK BUNGA TAPAK KUDA (Ipomoea pescaprae L. Sweet) SEBAGAI MEDIUM SINTESIS NANOPARTIKEL EMAS
}

\author{
Aswin Falahudin'1, Salprima Yudha $S^{1}$, Irfan Gustian¹, Morina Adfa1, \\ Charles Banon ${ }^{1}$, Teja Dwi Sutanto ${ }^{1}$ \\ 1) Jurusan Kimia, Fakultas Matematika dan IImu Pengetauan Alam, Universitas Bengkulu \\ Jalan W.R, Supratman, Kandang Limun, Kota Bengkulu, Indonesia \\ E-mail: salprima@unib.ac.id, sp.yudha.s@gmail.com
}

26 Desember 2019; 20 Januari 2020; 19 Maret 2020

\begin{abstract}
ABSTRAK
EKSTRAK BUNGA TAPAK KUDA (Ipomoea pescaprae L. Sweet) SEBAGAI MEDIUM SINTESIS NANOPARTIKEL EMAS. Pada penelitian ini, nanopartikel emas disiapkan melalui pendekatan green synthesis menggunakan ekstrak air bunga tapak kuda (Ipomoea pescaprae L. Sweet). Nanopartikel emas yang dihasilkan dianalisis menggunakan spektrofotometer UV-Vis, Mikroskop Leica, Particle Size Analyzer (PSA), Spektrofotometer Fourier Transform Infra-Red (FTIR) dan X-ray Difractometer (XRD). Hasil pengukuran PSA menunjukkan ukuran partikel terbaik, diperoleh dengan menggunakan perbandingan volume $1 \mathrm{~mL}$ larutan $\mathrm{HAuCl}_{4}$ dengan $9 \mathrm{~mL}$ ekstrak yang menghasilkan partikel dengan ukuran rata-rata 16,3 nm. Hasil penampakan dengan mikroskop cahaya, memperlihatkan partikel berbentuk bulat. Pergeseran bilangan gelombang pada spektrum infra-merah menunjukkan adanya interaksi antara metabolit sekunder dari ekstrak dengan material emas. Analisis XRD menunjukkan bahwa nanopartikel emas telah dapat dihasilkan dari kondisi reaksi ini.
\end{abstract}

Kata kunci : Nanopartikel emas, Ipomoea pescaprae (L) Sweet, Sintesis

\begin{abstract}
TAPAK KUDA (Ipomoea pescaprae L. Sweet) FLOWERS EXTRACT AS A MEDIUM FOR SYNTHESIZING GOLD NANOPARTICLES. In this study, gold nanoparticles were prepared via a green synthesis approach using Tapak Kuda (Ipomoea pescaprae L. Sweet) flowers extract. The resulting gold nanoparticles were analyzed using UV-Vis spectrophotometer, optical (?) microscope, particle size analyzer (PSA), Fourier Transform ...(FTIR) and $X$-ray...(XRD). PSA measurement results showed that the best particle size was obtained by using a volume ratio of $1 \mathrm{~mL} \mathrm{HAuCl} 4$ solution with $9 \mathrm{~mL}$ extract, which produced nanoparticles with an average size of $16.3 \mathrm{~nm}$. The results of the optical microscope analysis showed that the obtained particles was in spherical form. The wave numbers shift in the infra-red spectrum indicated an interaction between secondary metabolites from the flowers extract with gold material. XRD analysis shows that the gold nanoparticles were obtained under current condition.
\end{abstract}

Key words : Gold nanoparticles, Ipomoea pescaprae L. Sweet, Synthesis

\section{PENDAHULUAN}

Pendekatan sintesis nanopartikel emas (AuNPs) telah banyak berkembang dalam satu dekade ini seperti menggunakan metode kombinasi Chemical reduction dan Photoirradiation process (Niidome et al., 2003), Solvothermal (Ahmad et al., 2013) dan Gamma radiation (Misra et al., 2012). Penggunaan material ramah lingkungan menjadi salah satu alternatif pilihan dalam membuat nanopartikel, selain itu proses yang relatif simpel serta biaya produksi rendah menjadi alasan sehingga metode ini banyak dipilih (Shankar et al., 2004). Beberapa laporan terkini tentang keberhasilan sintesis nanopartikel emas (AuNPs) dengan metode green synthesis seperti menggunakan ekstrak alga coklat jenis Stoechospermum marginatum (Rajathi et al. 2012), kulit buah Lansium domesticum (Shankar et al., 2014), ekstrak daun Mentha piperita (Mubarakali et al., 2011). Salmalia malabarica gum (Ganapuram et al., 2015), ekstrak bunga Plumeria alba (Mata, Bhaskaran, dan Sadras 2015), dan ekstrak daun Parkia roxburghii (Paul et al., 2016). Seperti yang dilaporkan bahwa penggunaan ekstrak tanaman seperti Mimusops elengi sebagai bioreduktor dapat mereduksi Au (III) menjadi Au (0), adanya komponen polyphenolic dalam ekstrak, diketahui berperan sebagai agen penstabil pada permukaan AuNPs dan akan menghambat agregasi lebih lanjut (Majumdar, Bag, dan Ghosh, 2016). Ini sesuai dengan penelitian sebelumnya, bahwa adanya senyawa metabolit sekunder 
seperti triterpenoids, flavonoids dan phenolic pada ekstrak Lantana Camara bertindak sebagai agen pereduksi pada ion chloroaurate menjadi AuNPs (Dash, Bag, dan Hota, 2015).

Sejalan dengan kajian tersebut, penelitian ini mengkaji tentang pemanfaatan bunga dari tumbuhan tapak kuda (Ipomoea pescaprae L. Sweet) sebagai medium sekaligus agen yang dapat mereduksi ion emas menjadi nanopartikel emas di dalam larutan. Dalam aplikasinya, nanopartikel emas (AuNPs) telah diketahui mampu untuk mendegradasi zat warna (Ganapuram et al., 2015). Seperti yang dilaporkan, bahwa nanopartikel emas telah berhasil digunakan dalam mendegradasi pewarna seperti, zat warna metylene blue (MB) (Suvith dan Philip, 2014), Congo red (Ganapuram et al., 2015), Rhodamine B (Paul et al., 2016) dan Methyl red (Mata, Bhaskaran, dan Sadras 2015). Pada proses degradasi zat warna, nanopartikel emas bertindak sebagai electron transfer, AuNPs akan membantu proses pelepasan elektron dari ion $\mathrm{BH}_{4}^{-}$(donor) ke dyes (akseptor). Ion $\mathrm{BH}_{4}^{-}$yang merupakan nucleophilic dan dyes merupakan elektrophilic, selanjutnya AuNPs akan menerima elektron dari $\mathrm{BH}_{4}$ - dan akan mengirimkan ke dyes (MB) (Cheval et al., 2012)

Tumbuhan tapak kuda (Ipomoea pescaprae L. Sweet) merupakan jenis tumbuhan herbal, dengan bentuk batang yang menjalar dengan warna hijau kecoklatan, daun berbentuk bulat telur dan memilki bunga berwarna ungu kemerahan seperti yang ditunjukkan pada Gambar 1. Berikut merupakan klasifikasi dari tanaman tapak kuda :

$\begin{array}{ll}\text { Regnum } & \text { : Plantae } \\ \text { Divisi } & \text { : Magnoliophyta } \\ \text { Classis } & \text { : Magnoliopsida } \\ \text { Ordo } & \text { : Solanales } \\ \text { Familia } & \text { : Convolvulaceae } \\ \text { Species } & \text { : Ipomoea pescaprae L. Sweet }\end{array}$

(Alfaida, Suleman dan Nurdin., 2013).

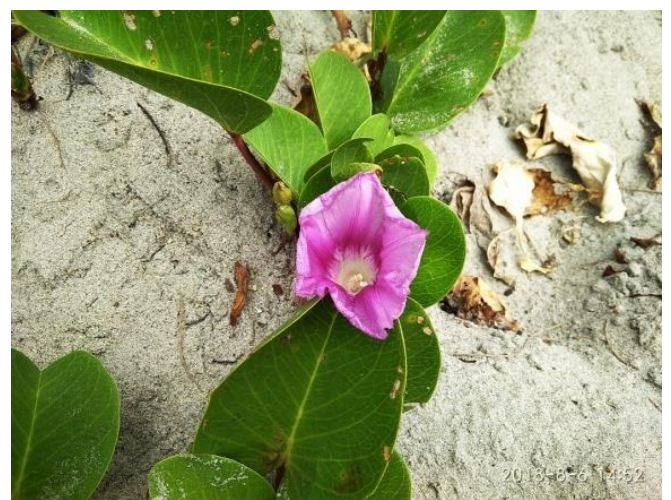

Gambar 1. Bunga tapak kuda (Ipomoea pescaprae L. Sweet).

Berdasarkan kajian analisis terhadap daun tapak kuda (Ipomea pescapra L. Sweet) bahwa daun tapak kuda memiliki kandungan metabolit sekunder seperti alkaloid, flavonoid, tanin dan steroid (Ali, Yamlean, dan Kojong. 2015). Penelitian sebelumnya menunjukkan, metabolit sekunder memiliki peran sebagai biorekduktor. Prosesnya diawali dengan adanya interaksi antara ion logam dan metabolit sekunder, yang akan mereduksi ion logam dan menjadi agen penstabil. Hasil kompleks dari ion logam dan interaksi antara kompleks yang sama akan membentuk nanopatikel logam yang kecil (Makarov et al., 2014). Informasi terkini menunjukkan bahwa pemanfaatan tumbuhan ini baru terbatas pada pemanfaatan ekstrak daun tapak kuda untuk mensintesis nanopartikel perak (AgNPs) (Arulmoorthy et al.(2015). Oleh karena itu, penelitian ini difokuskan pemanfaatan bagian lain dari tumbuhan tersebut, yaitu pada penggunaan ekstrak bunganya sebagai medium sintesis nanopartikel emas dan karakterisasinya.

\section{BAHAN DAN METODE}

\section{Bahan}

Chloroauric acid (Sigma Aldrich) digunakan sebagai prekursor dalam pembuatan nanopartikel emas. Aqua demineralisasi, bunga tapak kuda (Ipomoea pescaprae L. Sweet) yang tumbuh liar di Pantai Panjang Kota Bengkulu, Indonesia. Spektrofotometer UV-Vis Agilent Cary 60 digunakan untuk mengukur absorbansi larutan. FTIR dan XRD digunakan untuk analisis gugus fungsional dan kristalinitas dari nanopartikel emas yang dihasilkan.

\section{Metode}

Bunga tapak kuda (Ipomoea pescaprae L. Sweet) segar dibersihkan dari pengotor dan dilakukan pencucian menggunakan akuades. Proses ekstraksi senyawa yang larut dalam air mengikuti prosedur yang telah dilaporkan dengan sedikit modifikasi penambahan waktu yang digunakan untuk proses ekstraksi sampel (Mubarakali et al. 2011). Sebanyak 10 gram bunga segar, dimasukkan ke dalam erlenmeyer yang berisi $100 \mathrm{~mL}$ aqua demineralisasi, dan campuran dipanaskan pada suhu $60^{\circ} \mathrm{C}$ selama 15 menit sambil diaduk menggunakan magnetik stirrer. Setelah didinginkan pada suhu kamar, campuran disaring menggunakan kertas saring Whatman No. 1 untuk memisahkan filtrat dan residu yang tidak digunakan. Filtrat disimpan di dalam freezer untuk digunakan selanjutnya.

Sintesis nanopartikel emas mengacu pada penelitian sebelumnya oleh Suvith dan Philip .(2014), dengan sedikit modifikasi. Masingmasing sebanyak $4 \mathrm{~mL}$ dan $9 \mathrm{~mL}$ ekstrak dimasukkan ke dalam botol sampel, selanjutnya tambahkan larutan $\mathrm{HAuCl}_{4}(0,01 \mathrm{M})$ secara perlahan pada tiap larutan ekstrak, sambil diaduk menggunakan stirrer pada suhu ruang. Proses terbentuknya nanopatikel emas diamati dengan 
spektrofotometer UV-Vis (400 nm - $800 \mathrm{~nm}$ ). Karakterisasi pendukung dilakukan menggunakan Mikroskop Leica, Particle Size Analyzer (PSA), Spektroskopi Fourier Transform Infra-Red (FTIR) dan X-ray Difractometry (XRD).

\section{HASIL DAN PEMBAHASAN}

\section{Sintesis nanopartikel emas menggunakan ekstrak bunga tapak kuda}

Sintesis nanopartikel emas (AuNPs) dengan menggunakan pendekatan konsep green synthesis, telah dilakukan dengan memanfaatkan ekstrak air bunga tapak kuda (Ipomoea pescaprae L. Sweet). yang diperoleh dari Pantai Panjang Kota Bengkulu, berwarna coklat kemerahan.

Sintesis nanopartikel emas (AuNPs) dilakukan dengan 2 (dua) variasi perbandingan volume larutan antara ekstrak dan larutan $\mathrm{HAuCl}_{4}$. Seperti pada Tabel 1.

Tabel 1. Perbandingan volume larutan sintesis nanopartikel emas

\begin{tabular}{ccc}
$\begin{array}{c}\text { Kode } \\
\text { sampel }\end{array}$ & $\begin{array}{c}\text { Ekstrak bunga } \\
\text { tapak kuda }(\mathrm{mL})\end{array}$ & $\begin{array}{c}\text { Larutan } \\
\mathrm{HAuCl}{ }_{4} \\
(\mathrm{~mL})\end{array}$ \\
\hline Au-1 & 4 & 1 \\
Au-2 & 9 & 1 \\
\hline
\end{tabular}

Proses sintesis nanopartikel emas dilakukan pada temperatur ruang. Perubahan warna larutan terjadi secara perlahan ketika ekstrak Ipomoea pescaprae L. Sweet (Gambar 2a) yang ditambah larutan $\mathrm{HAuCl}_{4}$ setelah beberapa saat, dari warna coklat menjadi warna ungu (Gambar 2b dan 2c). Perubahan warna ini menjadi salah satu indikasi awal mulai terbentuknya nanopartikel emas di dalam campuran reaksi (Mubarakali et al., 2011). Perubahan warna pada larutan terjadi karena adanya perubahan sifat osilasi dari interaksi medan elektromagnetik pada nanopartikel logam, yang dikenal dengan Surface Plasmon Resonance (SPR) (Noruzi et al., 2011).

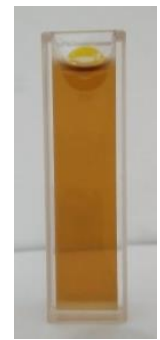

(a)

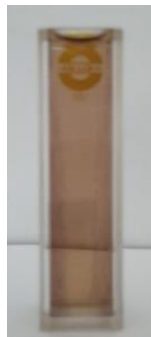

(b)

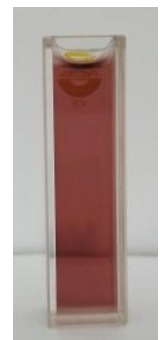

(c)
Gambar 2. Perubahan warna pada proses sintesis nanopartikel emas (a) ekstrak, (b) Au-1 dan (c) Au-2.

\section{Analisis Surface Plasmon Resonance (SPR) nanopartikel emas menggunakan Spektrofotometer UV-Vis}

Proses reduksi ion emas menjadi nanopartikel emas (AuNPs) oleh ekstrak bunga tapak kuda dapat diamati menggunakan spektrofotometer UV-Vis seperti ditunjukkan di dalam Gambar 3. Hasil analisis spektrofotometri UV-Vis terhadap larutan AuNPs pada Gambar 3 menunjukkan adanya puncak maksimum pada panjang gelombang 534 nm untuk Au-1 (Gambar 3a). Hal ini sejalan dengan penelitian sebelumnya (Singh et al., 2015) dan 528 nm untuk Au-2 (Gambar 3b) yang sejalan dengan penelitian sebelumnya menggunakan ekstrak Trichoderma sp. (Mishra et al., 2014). Berdasarkan spektrum tersebut juga tampak terjadi peningkatan absorbansi larutan seiring dengan lamanya proses sintesis koloid emas nanopartikel. Selain itu, terlihat adanya pengaruh volume ekstrak bunga tapak kuda terhadap puncak gelombang maksimum dari nanopartikel emas yang dihasilkan. Terlihat adanya pergeseran panjang gelombang yang ke arah lebih pendek seiring dengan meningkatnya konsentrasi ekstrak bunga tapak kuda yang digunakan (Mata, Bhaskaran, dan Sadras, 2015).
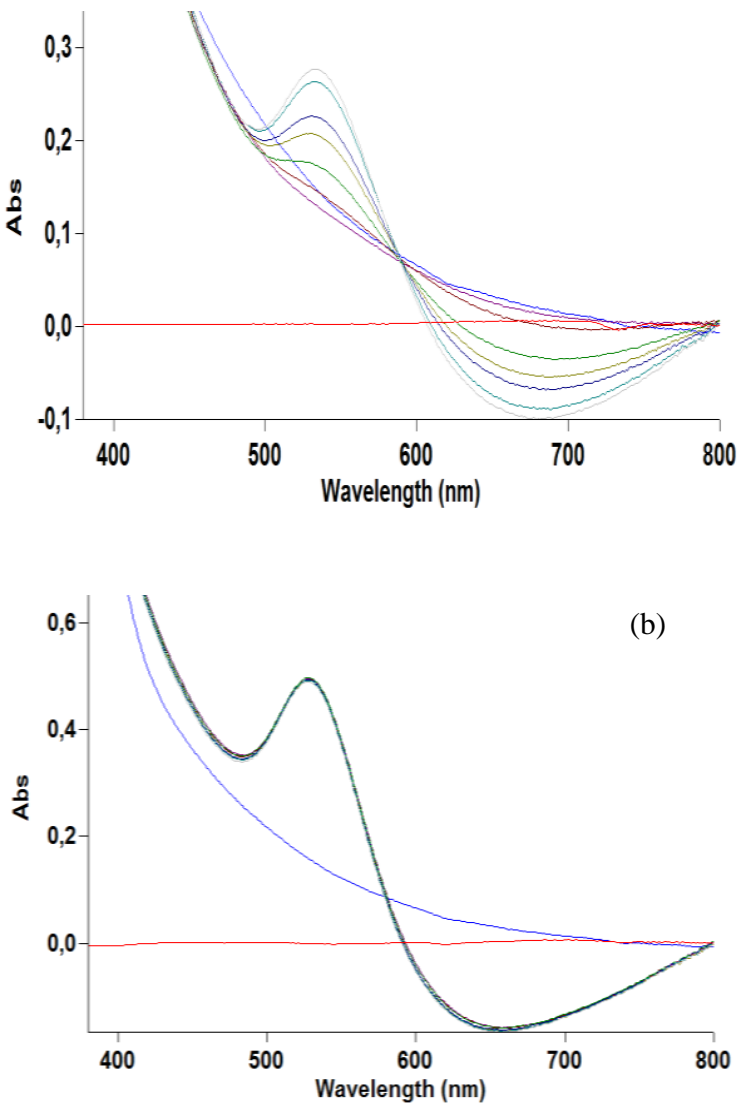

Gambar 3. (a) Au-1 waktu sintesis 30 menit hingga 60 menit, dan (b) Au-2 waktu sintesis 30 menit hingga 60 menit. 


\section{Analisis morfologi dan ukuran nanopartikel} emas (AuNPs).

Hasil pembacaan morfologi nanopartikel emas (AuNPs) menggunakan mikroskop optik Leica dengan perbesaran 35x ditampilkan pada Gambar 4. Gambar 4(a), merupakan pencitraan yang ditangkap oleh mikroskop Leica, terlihat warna larutan ekstrak berwarna coklat dan tidak terlihat adanya partikel. Larutan nanopartikel emas Au-1 dan Au-2 memperlihatkan warna yang berbeda dengan ekstrak, yakni berwarna ungu yang masing-masing ditunjukkan oleh Gambar 4(b) dan 4(c). Pada Gambar 4b menunjukkan banyak butiran spherical dari larutan Au-1, sedangkan Gambar 4(c) terlihat hanya sedikit butiran AuNPs yang dapat teramati pada perbesaran $35 x$ tersebut. Hal ini dapat digunakan sebagai penanda awal bahwa ukuran nanopartikel emas yang dihasilkan dari larutan $\mathrm{Au}-2$ lebih kecil dibanding dengan larutan $\mathrm{Au}-1$, karena partikel-partikel tersebut tidak dapat diamati oleh mikroskop cahaya tersebut, sehingga membutuhkan analisis menggunakan mikroskop elektron.
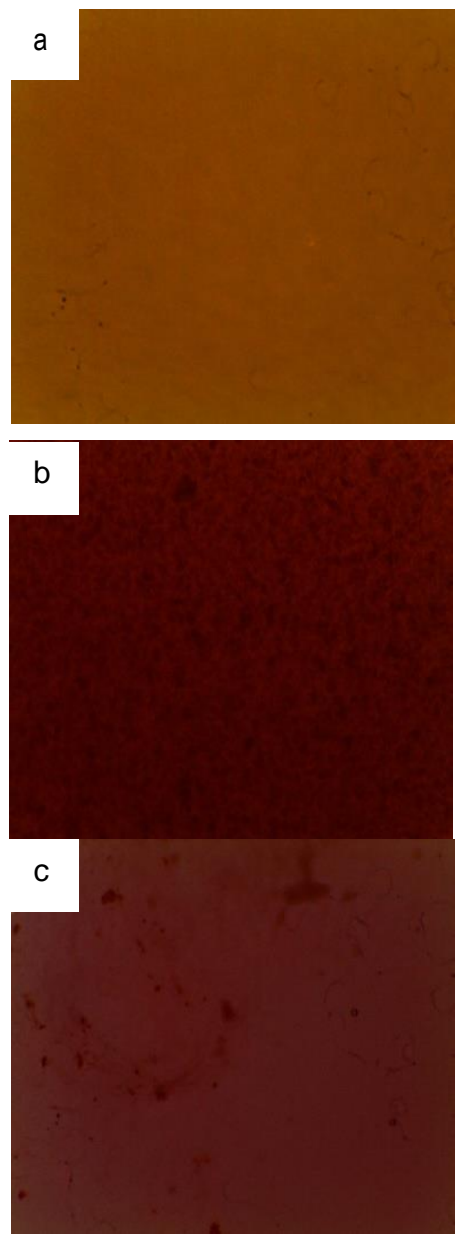

Gambar 4. Morfologi permukaan dari (a) ekstrak bunga tapak kuda, (b) Au-1, dan (c) Au-2.

Indikasi awal ini didukung oleh analisis ukuran partikel menggunakan Particle Size Analyzer
(PSA) terhadap larutan Au-1 dan Au-2 sebagaimana ditunjukkan pada Gambar 5. Gambar 5(a) menunjukkan hasil analisis PSA untuk larutan Au-1, dari data tersebut distribusi rata-rata ukuran partikel yakni 513,6 nm. Sedangkan distribusi rata-rata ukuran partikel untuk larutan Au-2 yakni 16,3 nm (Gambar 5(b)).

\section{Analisis gugus fungsi berbasis Spektrofotometri FTIR}

Analisis gugus fungsi yang terdapat di dalam ekstrak bunga tapak kuda, didahului dengan penguapan pelarut air dari ekstrak dengan cara pemanasan pada suhu $60{ }^{\circ} \mathrm{C}$ dan padatan yang diperoleh dianalisis menggunakan spektrofotometer FTIR. Hal yang sama dilakukan terhadap larutan Au-1 dan Au-2. Hasil analisis ditunjukkan pada dalam Gambar 6. Hasil analisis dari Au-1 dan Au-2 seperti pada Gambar 6(b) dibandingkan dengan padatan ekstrak murni bunga tapak kuda pada gambar 6(a).
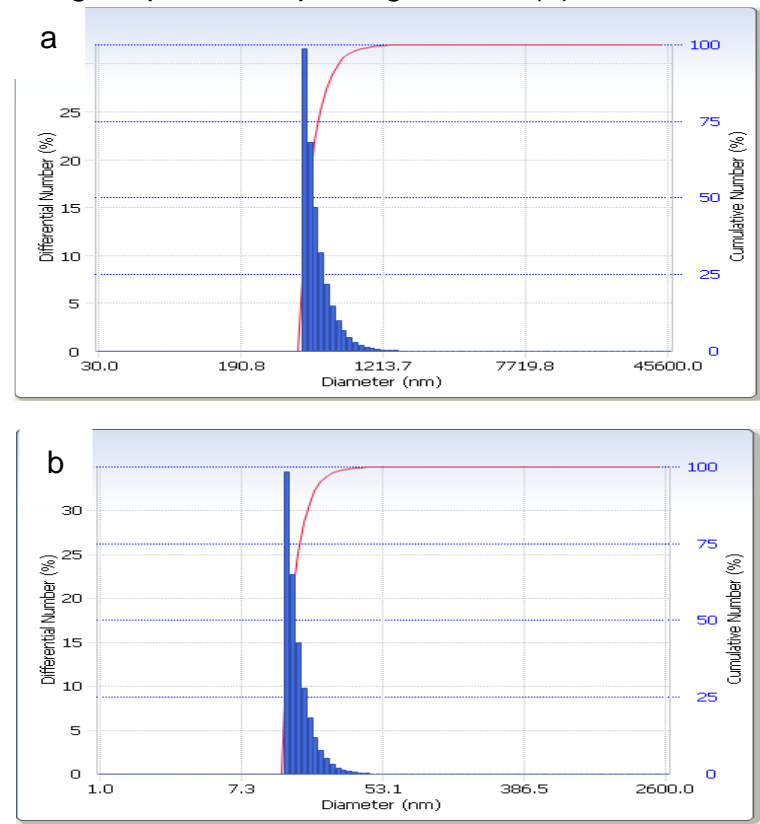

Gambar 5. Ukuran rata-rata distribusi partikel dari larutan (a) Au-1 dan (b) Au-2.

Pada Gambar 6(a). terlihat adanya vibrasi ulur melebar menunjukkan gugus hidroksil pada $3275 \mathrm{~cm}^{-1}$ (Arulmoorthy et al., 2015), vibrasi ulur dari C-H pada $2930 \mathrm{~cm}^{-1}$ (Daisy dan Saipriya 2012). Puncak vibrasi pada daerah $1592 \mathrm{~cm}^{-1}$ dan $1034 \mathrm{~cm}^{-1}$ masing-masing vibrasi dari $\mathrm{C}=\mathrm{C}$ aromatis (Noruzi et al., 2011) dan C-O dari hidroksil grup (C-OH) (Maity, Sen, dan Islam, 2012).

Pada gambar 6(b), menunjukkan adanya pergeseran kecil pada bilangan golombang untuk sampel Au-1 yakni $3267 \mathrm{~cm}^{-1}, 2922 \mathrm{~cm}^{-1}, 1633$ $\mathrm{cm}^{-1}$, dan $1018 \mathrm{~cm}^{-1}$. Sedangkan pada sampel Au-2 yakni $3308 \mathrm{~cm}^{-1}, 2939 \mathrm{~cm}^{-1}, 1641 \mathrm{~cm}^{-1}$, dan $1034 \mathrm{~cm}^{-1}$. Adanya puncak serapan cukup kuat 
pada $3267 \mathrm{~cm}^{-1}, 1633 \mathrm{~cm}^{-1}$ pada Au-1 dan 3308 $\mathrm{cm}^{-1}$ dan $1641 \mathrm{~cm}^{-1}$ pada Au-2 diindikasikan sebagai serapan dari air yang masih ada pada ekstrak sampel. Terjadinya pergeseran kecil bilangan gelombang serapan vibrasi ini diprediksi karena adanya ikatan koordinasi antara metabolit sekunder dengan permukaan nanopartikel emas (Shankar et al., 2004).
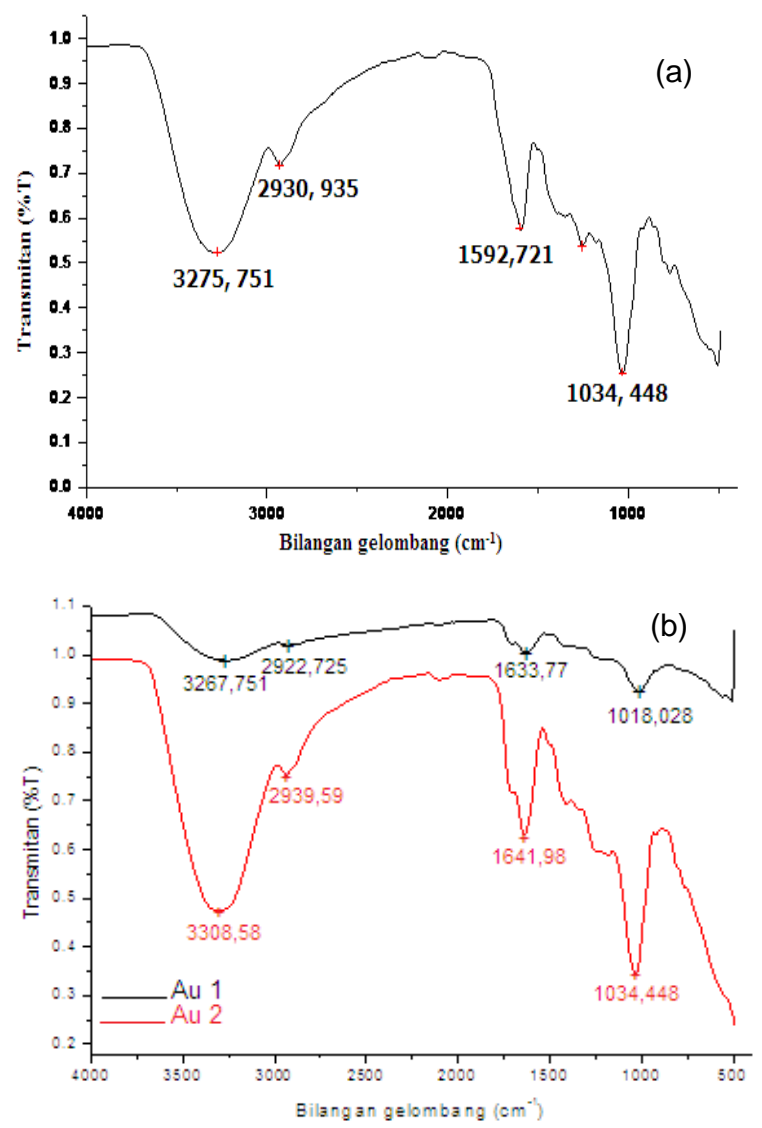

Gambar 6. Spektrum FTIR (a) Ekstrak bunga tapak kuda dan (b) nanopartikel emas Au-1, dan Au-2

\section{Analisis fasa kristalin nanopartikel emas.}

Analisis XRD dilakukan untuk mengidentifikasi fasa dari serbuk nanopartikel hasil sintesis yang telah diperoleh melalui pengeringan larutan reaksi $\mathrm{Au}-1$ dan $\mathrm{Au}-2$ pada suhu $60^{\circ} \mathrm{C}$. Hasil analisis ditunjukkan di dalam Gambar 7. Gambar 7(a) adalah difraktogram Au1 terdapat puncak difraksi pada $2 \theta$ yakni pada sudut $38,25^{\circ} ; 44,49^{\circ} ; 64,71^{\circ}$ dan $77,59^{\circ}$. Tidak jauh berbeda dengan Au-1, untuk Au-2 seperti yang tampak pada Gambar 7(b) menunjukkan pola difraksi yang hampir sama yang ditunjukkan hasil pola difraksi pada $2 \theta 38,21^{\circ} ; 44,45^{\circ} ; 64,67^{\circ}$ dan $77,69^{\circ}$. Hasil ini mengindikasikan kesesuaian dengan laporan penelitian yang telah mensintesis nanopartikel menggunakan ekstrak bunga Plumeria alba (Mata, Bhaskaran, dan Sadras, 2015).
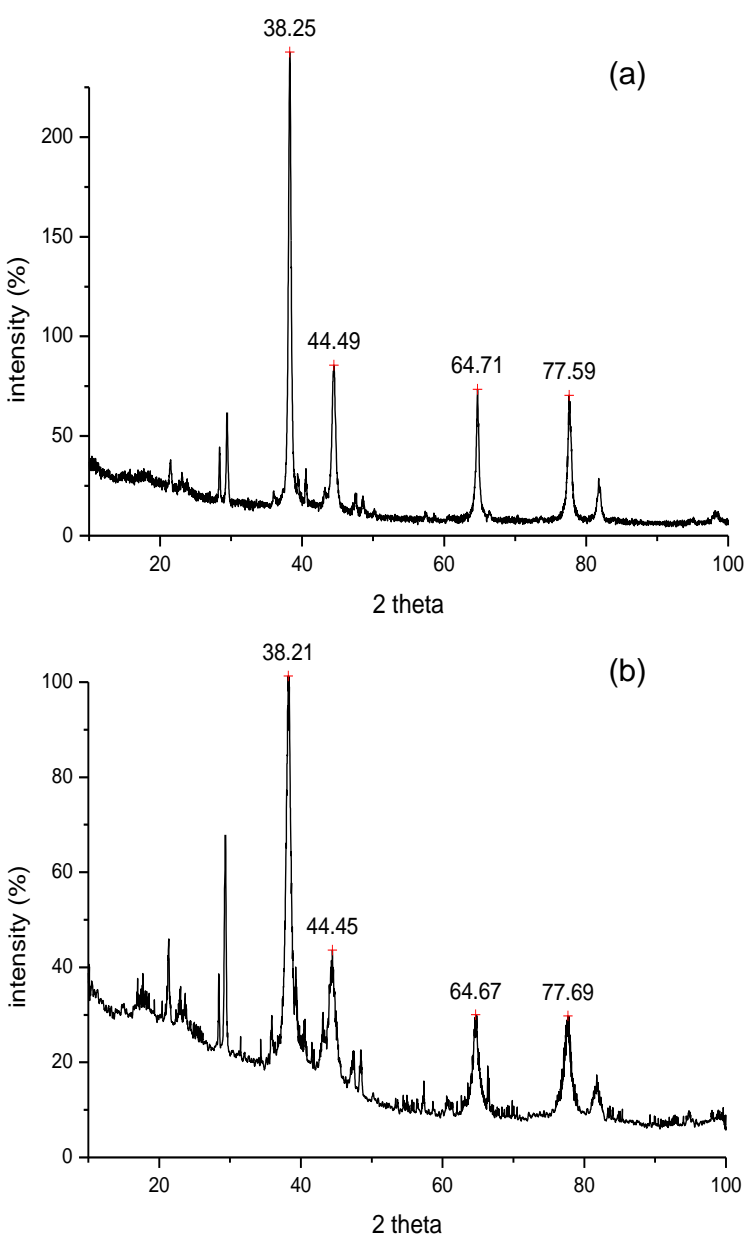

Gambar 7. Pola XRD nanopartikel emas (a) Au-1, dan (b) Au-2

\section{KESIMPULAN}

Nanopartikel emas telah berhasil disintesis dengan menggunakan media ekstrak bunga tapak kuda, sebagai bioreduktor sekaligus sebagai capping agent. Nanopartikel emas yang dihasilkan dari kondisi reaksi ini memiliki rata-rata ukuran partikel sebesar 16,3 nm dan serapan maksimum pada analisis spektrofotometry UVVis pada $528 \mathrm{~nm}$. Hasil analisis menggunakan FTIR menunjukkan pergeseran bilangan gelombang pada sampel yang mengandung nanopartikel emas, mengindikasikan adanya interaksi antara metabolit sekunder dengan emas dalam ukuran nano. Ukuran nanopartikel emas yang dihasilkan dengan kondisi terbaik adalah $16,3 \mathrm{~nm}$.

\section{UCAPAN TERIMA KASIH}

Kami ucapkan terima kasih kepada Direktorat Riset dan Pengabdian kepada Masyarakat (DRPM), Kementrian Riset, Teknologi dan Pendidikan Tinggi Republik Indonesian (KEMENRISTEKDIKTI) atas pendanaan penelitian ini pada Program Hibah Tim Pascasarjana 2018. 


\section{DAFTAR PUSTAKA}

Ahmad, T., I.A. Wani, I.H. Lone, A.Ganguly, N. Manzoor, A. Ahmad, J. Ahmed, dan A.S. Alshihri. 2013. "Antifungal activity of gold nanoparticles prepared by solvothermal method." Materials Research Bulletin, 48: 12-20. doi

http://dx.doi.org/10.1016/j.materresbull.201 2.09.069

Alfaida., S.M. Suleman, dan H.M. Nurdin. 2013. "Jenis-Jenis Tumbuhan Pantai di Desa Pelawa Baru Kecamatan Parigi Tengah Kabupaten Parigi Moutong dan Pemanfaatannya sebagai Buku Saku." eJipbiol, 1: 19-32.

Ali, N.W., P.V.Y. Yamelean, dan N.S. Kojong. 2015. "Pengaruh perbedaan tipe basis terhadap sifat fisik sediaan salep ekstrak etanol daun tapak kuda (Ipomoea pescaprae (L) Sweet)." Pharmacon Jurnal IImiah Farmasi, 4 : 110-16.

Arulmoorthy, M.P., S. Vasudevan, R. Vignesh, A.C. Rathiesh, dan M. Srinivasan. 2015. "Green synthesis of silver nanoparticle using Medicinal sand dune plant Ipomoea pescaprae leaf extract." International Journal of Science Inventions Today, 4 : 384-92.

Cheval, N., N, Gindy, C. Flowkes, dan A. Fahmi. 2012. "Polyamide 66 microspheres metallised with in situ synthesised gold nanoparticles for a catalytic application." Nanoscale Research Letters, 7 : 1-9.

Daisy, P., dan K. Saipriya. 2012. "Biochemical analysis of Cassia fistula aqueous extract and phytochemically synthesized gold nanoparticles as hypoglycemic treatment for diabetes mellitus." International Journal of Nanomedicine, 7: 1189-1202.

Dash, S.S., B.G. Bag, dan P. Hota. 2015. "Lantana camara Linn leaf extract mediated green synthesis of gold nanoparticles and study of its catalytic activity." Applied Nanoscience, 5: 343-50. doi:10.1007/s13204-014-0323-4.

Ganapuram, B.R., M. Alle, R. Dadigala, A. Dasari, V. Maragoni, dan V. Guttena. 2015. "Catalytic reduction of methylene blue and Congo red dyes using green synthesized gold nanoparticles capped by salmalia malabarica gum." International Nano Letter, 5 : 215-222. doi:10.1007/s40089-015-01583.

Maity, S., I.P. Sen, dan S.S. Islam. 2012. "Green synthesis of gold nanoparticles using gum polysaccharide of Cochlospermum religiosum ( katira gum ) and study of catalytic activity." Physica E: Lowdimensional Systems and Nanostructures, 4

$130-34$ doi:10.1016/j.physe.2012.07.020.

Majumdar, R., B.G. Bag, dan P. Gosh. 2016. "Mimusops elengi bark extract mediated green synthesis of gold nanoparticles and study of its catalytic activity." Applied Nanoscience, 6 : 521-528. doi:10.1007/s13204-015-0454-2.

Makarov, V.V., A.J. Love, O.V. Sinitsyna, S.S. Makarova, I.V. Yaminsky, M.E. Taliansky, dan N.O Kalinina. 2014. "“ Green Nanotechnologies: Synthesis of Metal Nanoparticles Using Plants." Acta nature, 6 : 35-44.

Mata, R., A. Bhaskaran, dan S.R. Sadras. 2015. "Green-synthesized gold nanoparticles from Plumeria alba flower extract to augment catalytic degradation of organic dyes and inhibit bacterial growth." Particuology. Chinese Society of Particuology, 1-9. doi:10.1016/j.partic.2014.12.014.

Mishra, A., M. Kumari, S. Pandey, V. Chaudry, K.C. Gupta, dan C.S. Nautiyal. 2014. "Biocatalytic and antimicrobial activities of gold nanoparticles synthesized by Trichoderma sp ." Bioresource Technology. Elsevier Ltd, 1-26. doi:10.1016/j.biortech.2014.04.085.

Misra, N., J. Biswal, A. Gupta, J.K. Sainis dan S. Sabharwal. 2012. "Gamma radiation induced synthesis of gold nanoparticles in aqueous polyvinyl pyrrolidone solution and its application for hydrogen peroxide estimation." Radiation Physics and Chemistry, 81 : 195-200. doi:10.1016/j.radphyschem.2011.10.014.

Mubarakali, D., N. Thajuddin, K. Jeganathan, dan M. Gunasekaran. 2011. "Plant extract mediated synthesis of silver and gold nanoparticles and its antibacterial activity against clinically isolated pathogens." Colloids and Surfaces B: Biointerfaces, 85 : 360-65. doi:10.1016/j.colsurfb.2011.03.009.

Niidome, Y., K. Nishioka, H. Kawasaki, dan S. Yamada. 2003. "Rapid synthesis of gold nanorods by the combination of chemical reduction and photoirradiation processes; morphological changes depending on the growing processes." Chem.Commun, 2376-2377.

Noruzi, M., D. Zare, K. Khoshnevisan, dan D. Davoodi. 2011. "Rapid green synthesis of gold nanoparticles using Rosa hybrida petal extract at room temperature." Spectrochimica Acta Part A: Molecular and Biomolecular Spectroscopy, 79 : 1461-65. doi:10.1016/j.saa.2011.05.001.

Paul, B., B. Bhuyan, D.D Purkayastha, dan S.S. Dhar. 2016. "Photocatalytic and antibacterial activities of gold and silver nanoparticles synthesized using biomass of 
Parkia roxburghii leaf." Journal of Photochemistry and Photobiology, B: Biology, 154 : $1-7$. doi:10.1016/j.jphotobiol.2015.11.004.

Rajathi, F.A.A., C. Parthiban, V.G. Kumar, dan P Anantharaman. 2012. "Biosynthesis of antibacterial gold nanoparticles using brown alga , Stoechospermum marginatum ( kützing )." Spectrochimica Acta - Part A: Molecular and Biomolecular Spectroscopy, 99 166-73. doi:10.1016/j.saa.2012.08.081.

Shankar, S., L. Jaiswal, R.S.L. Aparna, dan R.G.S.V. Prasad. 2014. "Synthesis, characterization, in vitro biocompatibility, and antimicrobial activity of gold, silver and gold silver alloy nanoparticles prepared from Lansium domesticum fruit peel extract." Materials Letters, 137: 75-78. doi:10.1016/j.matlet.2014.08.122.
Shankar, S.S., A. Rai, A. Ahmad, dan M. Sastry. 2004. "Rapid synthesis of $\mathrm{Au}, \mathrm{Ag}$, and bimetallic Au core - Ag shell nanoparticles using Neem ( Azadirachta indica) leaf broth." Journal of Colloids and Interface Science, 275 : 496-502. doi:10.1016/j.jcis.2004.03.003.

Singh, P., Y.J. Kim, C. Wang, R. Mathiyalagan, dan D.C. Yang. 2015. "The development of a green approach for the biosynthesis of silver and gold nanoparticles by using Panax ginseng root extract, and their biological applications." Nanomedicine, and Biotechnology, $1-8$. doi:10.3109/21691401.2015.1011809.

Suvith, V.S., dan D. Philip. 2014. "Catalytic degradation of methylene blue using biosynthesized gold and silver nanoparticles." Spectrochimica Acta Part A: Molecular and Biomolecular Spectroscopy, 118 526-32. doi:10.1016/j.saa.2013.09.016 